\title{
Some thoughts on the relationship between Old Testament studies and systematic theology
}

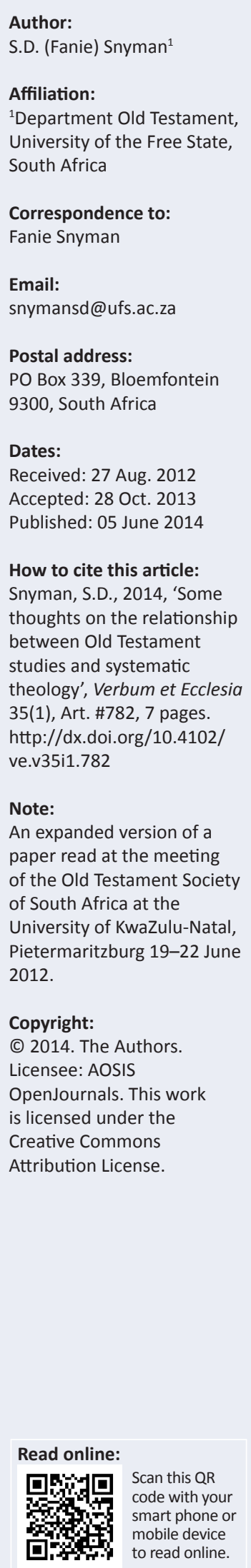

This article explores the relationship between Old Testament studies and systematic theology. After an overview of what Old Testament studies and systematic theology comprise, a historical overview of the problem is given. Two examples of the problem are provided (the USA and South Africa) before the author proceeds to his own views. The article argues that the two subjects have grown so far apart that it is doubtful whether the interaction between Old Testament studies and systematic theology will have any significant impact on the identity or content of either Old Testament studies or systematic theology. The identity of and the way in which the fields of study are practiced will not allow them to impact on one another. In an increasing way, theological disciplines will live side by side, each carrying on with what are perceived to be the cutting-edge questions within the respective fields of interest.

\section{Introduction}

Right at the outset, it must be stated that examining the relationship between Old-Testament scholarship and systematic theology is an extremely complex enterprise. Rahner (1979) wrote in this regard:

It is not an easy matter to bridge the gap between dogmatic theology and exegesis in the case of the New Testament and so it is hardly surprising that the same task is still more difficult in the case of the Old. (p. 177)

Both disciplines developed over the past few decades, and to keep abreast of only a part of the developments in only one of the fields is an impossible undertaking. It also needs to be said that the approach followed here will be from the perspective of Old-Testament studies.

\section{An identikit for Old-Testament studies and systematic theology}

How can the identity of the two respective subjects be described? The study of the Old Testament focuses first and foremost on the text of the Old Testament and can therefore be described as a text-oriented science. Old-Testament scholars read the text of the Old Testament. A second basic characteristic is that Old-Testament studies predominantly entails historical investigation. Whenever Old-Testament scholars read a text, they read it from a historical background with the aim of understanding the text from the historical context reflected in the text. The aim of Old-Testament studies is therefore fairly simple: Old-Testament scholars read the text of the Old Testament from a historical perspective in order to come to a better understanding of the text. From this basic precept, Old-Testament scholarship embarks on a wide variety of approaches. The Old Testament can be investigated, amongst others, from exegetical, historical, literary, text critical, archaeological, philological, geographical or hermeneutical points of view. The headings used in Old Testament Abstracts can be consulted for an overview of approaches followed in OldTestament scholarship.

How can the identity of systematic theology be described from the perspective of an Old-Testament scholar? Systematic theology has always been associated with the organising or ordering of central concepts in the Bible such as God, Christology, creation, eschatology, ecclesiology, the sacraments and church doctrines. Systematic theology as a discipline aims to provide a coherent account of Christian theology as a whole.

It is clear that the aims, object or thrust of these two disciplines are quite different. It should be noted that both 'systematic' and 'theology' are Greek-based words. It thus seems fair to say that systematic theology emerged within the framework of Greek thinking (Goldingay 2011:151) over

1.This remark is important for the context within which the paper was read originally. The paper was part of a discussion where another paper was read from the perspective of systematic theology. This explains why this article focuses on the Old Testament perspective of the debate. 
against an Ancient Near-Eastern frame of mind reflected in the Old Testament. Systematic theology is more interested in doctrines whilst the Old Testament is for the most part made up of narratives telling the story of Yahweh's great acts of salvation in the history of his people. It also consists of people responding to these acts of salvation in poetry in what we know as the prophetic literature, the psalms and wisdom literature. The very notion of narrative texts and poetry suggest open-endedness, allowing for texts with multiple meanings whilst systematic theology is more inclined towards unity and stability.

Systematic theology strives for unity in the diversity of Scriptures comprising both the Old and New Testaments. Old-Testament studies are quite happy with diversity within the unity of the one Old Testament, even to the point of accepting blatant contradictions. This is the main difference in approach between the two fields of study: Systematic theology looking for unity within the diversity of Scriptures, and Old-Testament studies looking for diversity within the unity of what is called the Old Testament or Hebrew Bible.

The history of Old-Testament theology illustrates this point clearly. Eichrodt (1975) posed the covenant as the unifying principle bringing together the whole of the Old Testament. The approach followed by Eichrodt was followed in countless endeavours in which a new centre or 'Mitte' was proposed for the Old Testament (Hasel 1984). Von Rad (1975) made us realise that such a unity cannot be found in the Old Testament when he published his Old-Testament theology. In this regard, Von Rad (1975) made the following statement:

Unlike the revelation in Christ, the revelation of Jahweh in the Old Testament is divided up over a long series of separate acts of revelation which are very different in content. (p. 115)

The Old Testament tells different stories, and all these stories put together make up in what we have as the Old Testament.

More recently, Rendtorff (2005), a student of Von Rad, came to the same conclusion but from a different methodological point of view. Old-Testament theology should listen to the different voices of the different corpora contained in the Old Testament, and only from there, themes or topics emerge that can be put together in a theology of the Old Testament. These themes or topics do not coincide with the rubrics found in handbooks on systematic theology but are the results of a careful reading of the Old Testament. Brueggemann (1997) also stressed the diversity in the Old Testament when he constructed his Old-Testament theology by making use of the metaphor of a court case where testimony and counter testimony exist side by side despite the fact that they may differ extensively. The approach followed by Gerstenberger (2002) is also telling. He advanced a theory on Old-Testament theology with the title: Theologies (plural!) of the Old Testament.

Looking at these marked differences, one has to ask whether and in what way a relationship is possible between these two distinctive subjects.

\section{Historical overview}

The study of the Old Testament is relatively new to the scene of theological studies. Although there had been a tradition of focusing on the text of the Bible in the so called Alexandrine school of thought, by and large, the Bible functioned throughout history as a source of proof texts to substantiate the dogmatic doctrines of the church with little or no attention to the historical background of the Biblical text. The birth of the study of the Old Testament independent from systematic theology is usually traced back to the inaugural lecture of J.P. Gabler on 30 March 1787 at the University of Altdorff in Germany. In his lecture, Gabler made a distinction between biblical and dogmatic theology. His classic formulation for this distinction is made early in the lecture:

There is a truly biblical theology, of historical origin, conveying what the holy writers felt about divine matters; on the other hand there is a dogmatic theology of didactic origin, teaching what each theologian philosophises rationally about divine things. (Sandys-Wunsch \& Eldridge 1980:137; Kraus 1970:53)

Gabler goes further to distinguish two phases in the process to be followed to arrive at a truly biblical theology. In the first phase, one needs to establish what the individual Bible authors meant when they wrote a particular book (SandysWunsch \& Eldridge 1980:148). It is necessary to distinguish different historical epochs in the Old and New Testament as well as for the different authors (Sandys-Wunsch \& Eldridge 1980:139). Gabler defined the scientific study of the Old Testament as an historical discipline. The historical task ahead is to distinguish between what pertains only to the time and circumstances of the books of the Bible and that which applied to all times and circumstances. 'Exactly thus will our theology be made more certain and more firm' (SandysWunsch \& Eldridge 1980:138). Gabler also distinguished a second phase: 'The other part of our task ... is ... a careful and sober comparison of the various parts attributed to each testament' (Sandys-Wunsch \& Eldridge 1980:141). Only ideas or thoughts common to the whole of the Bible can then be viewed as true doctrine of religion. These common thoughts must then be ordered to form a coherent whole (SandysWunsch \& Eldridge 1980:148).

For Gabler, the task of Biblical studies is clear: '... everything must be accomplished by exegetical observation only, and that with constant care ...' (Sandys-Wunsch \& Eldridge 1980:143). In the course of history, the study of the Old Testament developed in a direction where the emphasis will be on the historical questions pertaining to the text and to the literary features of the text. In some cases, more emphasis will be placed upon historical aspects, and in other cases, the emphasis will be more on the literary features of a text. With this kind of approach, attention to doctrinal issues kept on decreasing. With the advance of a historical understanding of Old-Testament texts, it became clear that Old-Testament texts cannot be used to substantiate church doctrines in systematic theology. Not long after the Gabler lecture, G.L. Bauer suggested a division of Biblical studies into two separate parts, the Old Testament and the New Testament. 
This development was instrumental in the alienation of the Old Testament from Christian theology (Lemche 2008:366).

Gabler's inaugural lecture took place in a particular time and Zeitgeist. The Renaissance that commenced in Italy in the 14th century heralded a completely new age for humankind in virtually all aspects of life. It was the time of the invention of the compass, gunpowder and book printing as well as the sea voyages of Columbus, Da Gama and Magellan. It was also during this time that Copernicus (born 1473) and Galileo Galilei (born 1564) discovered that the earth is not the centre of the universe but merely a planet like the other 'stars' that are visible in the sky. The earth is not flat but round; the earth is not stationary but rotating; the sun does not revolve around the earth but the earth revolves around the sun. The 15th and 16th centuries produced people such as Michelangelo, Leonardo da Vinci, Shakespeare and others.

The spirit of this new age also had a great influence on studying the Bible. There were two factors in particular that had a direct influence on studying the Bible. The one was the development of a historical awareness: the Bible is a document that originated in the past, and it must therefore be studied in the light of its historical context. The second factor was a revival of the interest in old classical literature. Ad fontes! [back to the sources!] was a slogan of the Renaissance and Humanism of that time. For Biblical science, this meant a turn to the text of the Bible (Hayes 1981:100-101; Kraus 1982:25). For this reason, the Reformers insisted that the Bible must be read in the original languages.

The Reformation took place within this spirit of the age. With the slogan of the Reformation, 'sola scriptura', the Bible was brought back to the centre of the church and theology. In contrast with the multiple meaning of texts that characterised the Middle Ages, great emphasis was now placed on the literal meaning of texts - the so-called sensus literalis. In addition, the historical context within which texts originated now increasingly received attention in the interpretation of the Bible. It was, in short, the time of the Enlightenment or Aufklärung.

Since the time of Gabler, Old-Testament studies developed more and more in the direction of a combination of historical and literary emphases on the text of the Old Testament. Some approaches put more emphasis on historical investigation and understanding whilst other approaches emphasise literary features more than historical interests.

Attending international meetings in the field of OldTestament studies, one cannot help to be overwhelmed by what can be seen as the increasing fragmentation of Old-Testament studies. What was considered to be subdisciplines have now grown into independent disciplines in their own right. There is an ever-increasing specialisation in every aspect of Old-Testament studies. One cannot be an OldTestament historian any more. What is needed nowadays are specialists in different historical periods in the course of the history of Israel. It is no longer possible to be a specialist on the prophetic literature. What is found now is specialists on different prophetic books or on prophetic books pertaining to a particular period in the history of Israel. These examples can be multiplied in almost every discipline in the field of Old Testament studies. We suffer from an overspecialisation in Old-Testament studies.

Part of the historical overview that must be taken into account is a growing recognition that the Old Testament does not only belong to Christian theology or to the church. OldTestament scholars would therefore find it hard to agree with a point of view such as the following (Rahner 1979):

The inclusion of a particular writing in the corpus of the Old Testament can be recognized as valid for us by reference to Christ, in that this corpus forms a written expression and description of the history of salvation, which, though pre-Christian, leads directly to Christ and possesses normative value for a Christian. (p. 184)

We as Old-Testament scholars share the Old Testament or Tenak with our Jewish colleagues for whom the Old Testament is the complete canon of Scriptures. Perhaps we should rephrase this sentence to its opposite: Jewish colleagues share their canon of Scriptures with the Christian tradition of interpretation. The Old Testament or Hebrew Bible can therefore not be viewed as that part of Scripture that was superseded by the New Testament. This development makes the study of the Old Testament a far more extensive ecumenical enterprise than a conversation between Roman Catholic and Protestant systematic theologians or between systematic theologians from different confessional viewpoints.

\section{Two exemplary views on the relationship between Old- Testament studies and systematic theology}

\section{The United States of America}

Brueggemann, arguably one of the most influential OldTestament scholars of our time, wrote his magnum opus in 1997. At the end of this book, he offered some thoughts on the relationship between Old-Testament theology and the New Testament and church theology (Brueggemann 1997:729733). In these last few pages of his Old-Testament theology, Brueggemann (1997:731) argued for the 'independent status of the Old-Testament text', recognising its 'powerfully polyphonic' voices. From the side of the Old Testament then, so Brueggemann argues (1997:732), it is theologically and historically important to insist that the connections between the two Testaments should be made from the side of the New Testament and not from the side of the Old Testament. The reason why Brueggemann insists on this premise is because he wants to guard against an 'inherently reductionist' approach that will reduce the polyphonic, elusive testimony of the Old Testament to the New Testament's Christological construal. The task of Old-Testament theology is to articulate, explicate, mobilise and make accessible and available the 
polyphonic, elusive and imaginative power of the Old Testament and then to offer it to the church (Brueggemann 1997:732). Brueggemann in this way sets a limit put down by the text of the Old Testament itself to the study of the Old Testament: it may not draw the connections between OldTestament theology and church theology.

Brueggemann's approach differs vastly from that of another influential Old-Testament scholar in the USA, Brevard Childs. He (Childs) is known for his canonical approach to the Old Testament and produced, amongst others, both an Old-Testament theology (Childs 1985) and a biblical theology comprising both the Old and New Testaments (Childs 1992). The canonical approach developed by Childs' books was criticised for being too close to a typical dogmatic approach as can be seen from the first chapters of his book on OldTestament theology.

\section{South Africa}

The most extensive and intensive debate I am aware of that took place between an Old-Testament scholar and a systematic theologian was between Ferdinand Deist and Johan Heyns at a conference commemorating the bicentennial celebration of J.P. Gabler's famous inaugural lecture in March 1787.

Deist's argument was that, in order to reflect on God, we make use of metaphorical language. If we want our Godlanguage to be Biblical, we should make use of the Biblical language about God. If that is the case, we shall have to take seriously the presupposition that God made himself knowable to humankind within the confines of history. Once that is granted, we are bound to speak of God in terms of and with the help of categories and vocabulary coming from history (Deist 1987:9). Religious language and the ordinary language of everyday activities are closely related. To gain an understanding of the language used to make utterances about God, we need textual analysis (Deist 1987:11). Deist made us of history and language to construct theological statements, and this is what Old-Testament scholars still do: historical investigation combined with literary sensitivity to the language used, are the tools we use to interpret the Old Testament.

Heyns (1987:20) operates with the construct of a threestorey structure, which he named revelation facts, revelation testimony and revelation proclamation. God revealed himself within history (the category of revelation facts). These revelation facts are transformed into revelation testimonies when the authors of the Bible wrote down the facts, and in this way, it became revelation. Ultimately these revelation testimonies of the Biblical authors are proclaimed, hence the third category of revelation proclamation (Heyns 1987:23). For Heyns (1987:24), the focus of biblical theology is on the word referring to a phenomenon whilst systematic theology focuses more on the phenomenon to which the word refers. The focus in biblical theology is on particularity whilst the focus in systematic theology is on universality. In this way, systematic theologians go further that their Biblical counterparts. The focus shifts from the historical conditions of a particular situation to the doctrinal implications that this text may have in combination with other texts (Heyns 1987:26). Systematic theology has to do with the total message of the total Scripture within the totality of its dynamic workings (Heyns 1987:26).

A second encounter between an Old-Testament scholar and a systematic theologian took place between J.H. le Roux and (once again) J.A. Heyns on the occasion of Heyns' retirement from the Faculty of Theology at the University of Pretoria at the end of 1993. As can be expected, the issue Le Roux took up with Heyns is his views on the Bible. According to Le Roux (1994:35-36), Heyns does not make sufficient room for the human side of Scripture; too much emphasis is place on the divine part of the origin of the Bible. According to Le Roux (1993:36), the Holy Spirit will guard the humanness of Scripture. The Holy Spirit acts as the first exegete, and all human errors are safe in the hands of the Holy Spirit. The critical question posed to Heyns by Le Roux is whether Heyns took note of developments in the study of the Bible especially with regard to critical scholarship as the result of the Aufklärung (Le Roux 1994:42-46). Had Heyns done so, Le Roux wondered, would Heyns still have maintained the same views on Scripture? Heyns responded to this criticism by acknowledging that the core of Le Roux's critical remarks centred around Heyns' views on Scripture (Heyns 1994:161). Heyns graciously accepted the criticism by acknowledging that he does indeed have a limited knowledge of the results of modern Biblical science and hermeneutics (Heyns 1994:162). He then went on to caution both systematic theologians and biblical scholars that the route Le Roux envisages as a result of insights gained from research within biblical scholarship was a 'dangerous one'.

It is clear from this second encounter that the gap between Biblical scholarship and systematic theologians has widened. The sharp criticism from Le Roux is valid whilst it seems that Heyns, on the one hand, was unaware of developments in the Old and New Testament scientific research leading Biblical scholars to ask the kind of questions Le Roux asked and, on the other hand, not willing to concede a rethinking of his own point of view in light of developments in the field of Biblical science.

\section{Two examples: God and the view of Scripture in Old-Testament scholarship and systematic theology God}

If one adheres to the very basic assumption that theology has to do with God, there is also a marked difference between Old-Testament studies and systematic theology. In systematic theology, God is described as the Triune God who revealed himself as Father, Son and Holy Spirit. In the Old Testament, the emphasis is on the one God (Dt 6:4) who made himself 
known to Israel in the midst of a polytheistic environment. In no way can the doctrine of the Trinity be read back into the Old Testament. The Old Testament does speak of God as Father but then only in a few parts (Dt 32:6; II Sm 7:14; I Ki 17:13; I Ki 22:10; 28:6; Ps 2:7; 68:6; 89:27; Is 63:16; 64:8; Jr 3:4, 19; Jr $31: 9 ; \mathrm{Ml} 1: 6 ; 2: 10$ ) so that the notion of God as Father cannot be seen as one of the dominant metaphors used in connection with God (Snyman 1998:47-53). In the Old Testament, the idea of a son of God is found, but it refers to either Israel, the people of God (Ex 4:22; Hs 11:1), or to the king as an adopted son of God, indicating the close relationship that ought to exist between God and the ruling king (Ps 2, 89, 110). In some other texts, members of the heavenly council were also called sons of God (Merrigan \& Lemmelijn 2006:27). The Hebrew concept of the spirit (ruach) refers to vitality, the breath of life coming from God. When used in connection with God, it is seen as part of God's being (Merrigan \& Lemmelijn 2006:2930) that may temporarily be bestowed upon people to equip them for tasks they had to perform.

God is described in many different ways in the Old Testament. One can imagine that in a corpus of literature spanning more or less a 1000 years many different views on God will emerge. The emphasis is more on what God did than on the peculiar characteristics God may have. What God did sometimes seem to be incoherent and is not always understood by people.

\section{The view on Scripture in Old-Testament scholarship and systematic theology}

To compare the different views that systematic theologians and Old-Testament scholars have on the issue of Scripture will illustrate the difference in approach. The doctrine of the inspiration of Scripture is important in systematic theology and a doctrine that one will find in any handbook on systematic theology. As the study of the Old Testament has been described as primarily a text-oriented investigation, Old-Testament scholars by profession read the text of the Old Testament.

Old-Testament scholars read the Old Testament in a very careful way. When reading the Old Testament in a careful way, one cannot help but realise the humanness of the document we call the Old Testament. The Old Testament was written by countless persons over a period spanning several centuries. When reading this material, one realises that it was written by human beings living in a particular historical time frame with their own viewpoints, prejudices, social status, political and religious convictions and probably a host of other factors as well. The origin of Old Testament books or corpora of Scripture is the result of extremely complex processes that can only partly be reconstructed by theories on what might have happened in the process of the compilation of what we have as the Old Testament.

Once the canon was formed by the different books and more or less outlined, the editing of Hebrew editions of the Old Testament was still in progress. To a certain extent, we may say that we are still busy writing the Old Testament as new editions of the Hebrew text of the Old Testament are prepared and published.

To accommodate an inspiration theory within this complex process of the origin and canonisation of the Old Testament becomes seriously problematic (Snyman 2003:459-473). Where does the inspiration of the Old Testament start? Did inspiration start with the oral phase of transmission, or did it start with the very first time that the oral material was written down? Did inspiration start when a prophet uttered his prophesy or when his prophesies were written down? Or did inspiration start when somebody wrote a prophecy under the name of a well-known prophet from long ago and presented it as originating from that ancient prophetic figure? Did it start with the Egyptian wisdom teacher who once uttered a wisdom saying that was subsequently written down and eventually taken up in die wisdom literature of the Old Testament?

Where does inspiration end? Does the notion of inspiration only apply to the original speakers or authors of the Bible as Heyns (1973:78) claims? If that is the case, we have ended up with a Bible devoid of any inspiration simply because the autographa (if ever there were autographa) are no longer available to us. What we have is only copies of copies of copies of manuscripts. If we want to adhere to the notion of the inspiration of Scripture, inspiration must include those countless people who copied ancient manuscripts. Does inspiration also include translations of Biblical texts? If we keep in mind that the version of the Old Testament used or quoted from in the early years of Christianity was most probably the Septuagint, translations should also be regarded as inspired by the Holy Spirit.

The encounter that Old-Testament scholars have with the text of the Old Testament questions the compatibility of inspiration theories from systematic theology with the knowledge we have on the origin of the Old Testament.

\section{The way forward}

Is there in a time of ever-increasing specialisation still a need for interaction between Old-Testament studies and systematic theology? This question needs to be asked because, even in the field of Old-Testament studies, it is virtually impossible to keep up with the latest developments in the different fields of what make up Old-Testament study today. We suffer from an information overload. Even within the confines of the Christian canon of Scriptures, there is little cooperation. Biblical theology as a field of study that is trying to bring together the Old and New Testament is not one of the current hotspots in the field of biblical studies. One can go even one step further: even within Old-Testament studies, cooperation is decreasing. If one wants to keep up with studies on the book of Jeremiah, there is little time left for studying the latest developments in Pentateuch theories. If this is the case in the field of Old-Testament studies, it will come as no surprise to discover that the same can be said for 
systematic theology or for any other discipline in the field of theology. The different loci of dogmatic theology require too much to handle at the same time. Speaking from a historical point of view, Old-Testament scholars may feel that 'we are free at last' wrestling ourselves from the bondage of dogmatic doctrines that kept us hostage for so many years. The forces of history will tend to keep us more and more apart rather than bringing us closer together.

Systematic theology must also reconsider whether it is still in need of Old-Testament studies. Does one have to have thorough knowledge of the Old Testament to be a good systematic theologian? My answer to this question would be no. It is not necessary to have a thorough knowledge of the issues that keep Old-Testament scholars busy in order to be a good systematic theologian. Is it fair to expect from systematic theologians to be knowledgeable about the latest theories on the authorship and origin of the Pentateuch or the latest theories on when and how the prophetic books originated or on the latest developments in the field of wisdom theology? Do systematic theologians need to know which one was first: J or D? More importantly, does the answer to the question matter for systematic theologians? I sometimes get the feeling that systematic theologians are at best not interested or at worst simply bored with the detail with which we examine a text whilst we as Old-Testament scholars all too often lose sight of the larger picture.

Scholars in the field of Old-Testament studies must consider whether there is still a need to engage in systematic theology. Does one have to have a thorough knowledge of systematic theology to be a good Old-Testament scholar? In what way will a thorough knowledge of systematic theology benefit the study of the Old Testament? From the side of Old Testament studies, we must ask ourselves whether we pose the same kind of questions as our colleagues in systematic theology. I do not think that we do, and neither do we ought to. Likewise, I suspect that we as Old-Testament scholars are interested in questions quite different from the questions asked in systematic theology.

I want to illustrate my point with a metaphor of a game that people play. In the 1987 debate, Ferdinand Deist used the metaphor of a game we play when doing theology. Initially, so Deist explained, the game theologians played was understood as a relay race where the stick was passed on from the Old-Testament scholar to the New Testament scholar and eventually to the systematic theologian who will in turn pass it on to the practical theologian who will then make it to the finishing line (Deist 1987:12). This approach was illustrated by Jonker (1979:84) (one of the few systematic theologians who addressed the issue of the relationship between Old-Testament studies and systematic theology) in a closing remark in an essay on the issue of the relationship between systematic theology and Old-Testament studies. In this article, he stated that what systematic theology needs is a deeper engagement with the Old Testament, and in this way, Old-Testament scholars could be of tremendous help to systematic theologians. Clearly the idea is that Old-
Testament scholars must hand the results of their research to the systematic theologians. The same approach is advocated by Heyns (1987:26) when he says that systematic theologians should 'always return to Scripture and the results of Biblical Theology only to depart from there again'.

John De Gruchy (1994:282-285) is another South African systematic theologian who addresses the issue of the relation between Old-Testament studies and systematic theology. He sees the resonance between Old-Testament scholarship and systematic theologians in the approaches that they share (De Gruchy 1994:284). Furthermore, Old-Testament scholarship enables systematic theologians to understand Hebrew faith and obedience, unbelief and disobedience in different forms and contexts. In particular, De Gruchy (1994:285) is interested in the way in which Old-Testament scholarship understands the relationship between faith and practice, doctrine and ethics. De Gruchy is interested in themes such as suffering, poverty, liberation, justice, the land and idolatry (1994:285). He recognises the importance of Old-Testament studies and is interested in what to expect from studies in the Old Testament. However, the agenda comes from systematic theology. Old-Testament studies are helpful in so far as they inform questions and issues studied in systematic theology.

According to Deist, the game changed. Deist changed the game metaphor from a relay race to that of a soccer game. Like in a soccer game where the ball is kicked around by different players with the aim of scoring a goal, theologians play a game with the ball consistently passed between Old Testament, New Testament scholars and systematic theologians. According to Deist (1987:12), it is impossible for a systematic theologian to speak about God without making use of biblical language and likewise it is impossible for a biblical theologian to speak about God without making use of contemporary language. In this sense, 'we are all theologians' (Deist 1987:12). I think what Deist had in mind with the use of the metaphor of a soccer game is that theologians from different angles should be in constant communication with one another. Scholars from the various fields of theology should take note of what is happening in the other fields and respond to that development or to make developments in one field part of the practice in the discipline they study. His own contribution serves as a case in point: from the side of Old-Testament studies, he stated his views on how the relationship between Old-Testament studies and systematic theology may function (Deist 1987:1-17).

The game we play on the theological field with the Bible and the language we use when speaking about God changed once more. What happens nowadays is that we play different games with the same ball (the Bible). To play different games with the same ball is something that happened in our childhood days. As children, we could have played tennis with a tennis ball, but that same tennis ball could just as well have been used for a game of cricket or a kind of baseball or even soccer. That is more or less what happens nowadays: we play different games with the same ball we call the Bible. Although we as theologians all make use of the Bible, some of 
us play the game of systematic theology, others play the OldTestament game or the New Testament game, others like to play practical theology. There is still a loose resemblance, but in effect, it boils down to different games we play, and we are only mildly interested in the games others play with the same ball we use to play our game.

However, the times we live in do not allow us to make absolute statements. Of course, there will be systematic theologians who will want to enter into a debate with their Old-Testament colleagues and vice versa (cf. MacDonald 2006). I however expect that only a few scholars from either side would venture in this direction. When occasionally some debate takes place, interesting viewpoints will be shared, but I doubt whether the interaction will have any significant impact on the identity or content of either Old-Testament studies or systematic theology. The identity and the way in which the subjects are practiced will not allow it to happen.

From the side of Old Testament studies, one could mention issues relevant to South Africa like the really complex God that Old-Testament believers encountered, the role that narrative should play in presenting a theology, the role of the wisdom traditions which were incidentally an ignored area of study within Old-Testament studies until recently, the land as theological theme (no one would deny that the land issue is currently one of the burning issues in South African society with little or no theological reflection on it), the contribution of the Old Testament to the debate on nature and nature preservation, the issue of theodicy and the question of wealth and poverty and social justice in the Old Testament.

\section{Conclusion}

I think it is wishful thinking to entertain the thought that systematic theology and Old Testament studies will come together for mutual discussions and agree on the topics discussed. Does it ever happen that a systematic theologian publishes articles in Old-Testament journals? My guess is that it does not happen or at best only on rare occasions. Are Old-Testament scholars invited to read papers at conferences in the field of systematic theology? I suspect that it does not happen either, except on rare occasions. That this is the fact of the matter does not mean that we are rivals in the field of theology or that one way of being a theologian is better or more sophisticated or more true to what it means to be a theologian. It means that we pursue our respective fields of interest each in their own way. In an increasing way, theological disciplines will live side by side, each carrying on with what are perceived to be the cutting-edge questions within the respective fields of interest. The public will receive fewer comprehensive 'Biblical' or dogmatic answers to theological or ethical matters. Questions will be answered from an Old or New Testament perspective or from the perspective of systematic theology or Christian ethics. The public and the church must learn to live with more than one answer, given from the angle of a particular branch of theology.

There is then no reason for an uneasy tension between systematic theology and Old-Testament studies. These two theological enterprises have grown so far apart from one another that a relationship of tension is not necessary nor is there any reason for tension. Scholars from the field of the Old Testament will sometimes look in amazement (and perhaps in disbelief) at what their colleagues in systematic theology are doing. Systematic theologians will also from time to time look at Old-Testament scholars and then try to come to grips with what on earth these fellows are doing in their meticulous reading of Old-Testament texts. They will then both smile at one another and return to their respective fields of interest.

\section{Acknowledgements Competing interests}

The author declares that he has no financial or personal relationship(s) that may have inappropriately influenced him in writing this article.

\section{References}

Brueggemann, W., 1997, Old Testament theology: Testimony, dispute, advocacy, Fortress Press, Minneapolis.

Childs, B.S., 1985, Old Testament theology in a canonical context, SCM Press, London.

Childs, B.S., 1992, Biblical theology of the Old and New Testaments: Theological reflection on the Christian Bible, SCM Press, London.

Deist, F.E., 1987, 'Relatiwisme en Absolutisme: Kan dit oorkom word? Oor "Bybelse" en "Dogmatiese" Teologie', in W.S. Prinsloo \& W. Vosloo (reds.), Ou Testament teologie: Gister, vandag en môre, bl. 1-17, NG Kerkboekhandel, Pretoria.

De Gruchy, J., 1994, 'The future of Old Testament studies from the perspective of systematic theology', Old Testament Essays 7(4), 282-285.

Eichrodt, W., 1975, Theology of the Old Testament, SCM Press, London.

Gerstenberger, E.S., 2002, Theologies of the Old Testament, T \& T Clark, Edinburgh.

Goldingay, J., 2011, Key questions about Biblical interpretation: Old Testament answers, Baker Academic, Grand Rapids. PMid:22053200, PMCid:PMC3203874

Hasel, G.F., 1984, Old Testament theology: Basic issues in the current debate, 3rd rev. and expanded edn., Eerdmans, Grand Rapids.

Hayes, J.H., 1981, An introduction to Old Testament study, Parthenon Press, Nashville.

Heyns, J.A., 1973, Brug tussen God en mens: Oor die Bybel, NG Kerkboekhandel, Pretoria.

Heyns, J.A., 1987, 'Respons op F E Deist, Relatiwisme en Absolutisme: Kan dit oorkom word? Oor "Bybelse" en "Dogmatiese" Teologie', in W.S. Prinsloo \& W. Vosloo (reds.), Ou Testament teologie: Gister, vandag en môre, bl. 18-28, NG Kerkboekhandel, Pretoria.

Heyns, J.A., 1994, "n Weerwoord', Skrif en Kerk 15(1), 156-176.

Jonker, W.D., 1979, 'Die Ou Testament in die dogmatiek', in D.H. Odendaal, B.A. Müller \& H.J.B. Combrink (reds.), Die Ou Testament vandag: Huldigingsbundel opgedra aan prof PA Verhoef, bl. 75-85, NG Kerk-Uitgewers, Kaapstad.

Kraus, H.J., 1970, Die Biblische Theologie. Ihre Geschichte und Problematik, Neukirchener Verlag, Neukirchen-Vluyn.

Kraus, H.J., 1982, Geschichte der Historisch-kritischen Forschung des Alten Testaments, 3 durchgesehener erweiterte Auflage, Neukirchener, Neukirchen-Vluyn.

MacDonald, N.B., 2006, Metaphysics and the God of Israel: Systematic theology of the Old and New Testaments, Baker Book House, Grand Rapids.

Lemche, N.P., 2008, The Old Testament between theology and history: A critical survey, Westminster John Knox Press, Louisville.

Le Roux, J.H., 1993, A Story of two ways: Thirty years of Old Testament scholarship in South Africa, Verba Vitae, Pretoria. (Old Testament Essays, Supplement Series 2).

Le Roux, J.H., 1994, 'God se brug na die mens: lets goddeliks of iets mensliks?', Skrif en Kerk 15(1), 27-51.

Merrigan, T. \& Lemmelijn, B., 2006, 'Van de God der Vaderen naar God de Vader: Het christelijk triniteitsdenken en zijn oudtestamentisch achtergrond', in T. Merrigan, C. Moonen \& K. Struys (reds.), Triniteit - Een kruis erover?, bl. 21-34, Halewijn, Antwerpen.

Rahner, K., 1979, Theological investigations, vol. XVI, Experience of the Spirit: Source of theology, Darton, Longman \& Todd, London.

Rendtorff, R., 2005, The canonical Hebrew Bible: A theology of the Old Testament, Deo Publishing, Leiden.

Sandys-Wunsch, J. \& Eldredge, L., 1980, 'J P Gabler and the distinction between biblical and dogmatic theology: Translation, commentary and discussion of his originality', Scottish Journal of Theology 33, 133-158. http://dx.doi.org/10.1017/\$0036930600047311

Snyman, S.D., 1998, “'U is tog ons Vader!” Oor die vaderskap van God in die Ou Testament', Nederduitse Gereformeerde Teologiese Tydskrif 39(1/2), 47-53.

Snyman, S.D., 2003, 'Oor die inspirasie van die Bybel: 'n Perspektief van 'n Ou Testamentikus', Verbum et Ecclesia 24(2), 459-473.

Von Rad, G., 1975, Old Testament Theology, vol. I, SCM Press, London. 